\title{
Methods for Estimating Optimum Plot Size for 'Gigante' Cactus Pear
}

\author{
Bruno V. C. Guimarães ${ }^{1}$, Sérgio L. R. Donato ${ }^{2}$, Ignacio Aspiazú ${ }^{3}$, Alcinei M. Azevedo ${ }^{4} \&$ Abner J. de Carvalho ${ }^{3}$ \\ ${ }^{1}$ Departamento de Ciências Agrárias, Instituto Federal do Amazonas, São Gabriel da Cachoeira, Amazonas, \\ Brazil \\ ${ }^{2}$ Setor de Agricultura, Instituto Federal Baiano, Guanambi, Bahia, Brazil \\ ${ }^{3}$ Departamento de Ciências Agrárias, Universidade Estadual de Montes Claros, Janaúba, Minas Gerais, Brazil \\ ${ }^{4}$ Instituto de Ciências Agrárias, Universidade Federal de Minas Gerais, Montes Claros, Minas Gerais, Brazil \\ Correspondence: Bruno V. C. Guimarães, Departamento de Ciências Agrárias, Instituto Federal Baiano, BR 307, \\ km 03, Estrada do Aeroporto, São Gabriel da Cachoeira, AM, Brazil. Tel: 55-779-9121-4608. E-mail: \\ bvinicius20@yahoo.com.br
}

Received: May 13, 2019

Accepted: June 22, 2019 Online Published: August 31, 2019

doi:10.5539/jas.v11n14p205

URL: https://doi.org/10.5539/jas.v11n14p205

The research is financed by Coordenação de Aperfeiçoamento de Pessoal de Nivel Superior (CAPES, Brazil)-Finance Code 001.

\begin{abstract}
The optimum plot size for 'Gigante' cactus pear can be estimated by several methods; thus, ultimately aiming for efficiency, simple use and high precision, the objective of this study was to compare methods for estimating plot sizes: modified maximum curvature method, Hatheway's convenient plot size method, linear and quadratic response plateau models, and comparison of variances method for evaluating phenotypic characteristics in experiments with 'Gigante' cactus pear. Plot sizes were estimated by conducting a uniformity trial. Estimated optimum plot sizes varied with the method and vegetative characteristic. The quadratic response plateau regression estimated the largest plot sizes, whereas Hatheway's method estimated the smallest plot sizes. Comparison of variances method estimated intermediate plot sizes in comparison with the other methods for most measured characteristics. Plots sizes estimated by modified maximum curvature method are more consistent with results reported by studies on 'Gigante' cactus pear. 10 basic unit plot sizes estimated by the linear response plateau model can be used with high precision and practical feasibility for growing cactus pear, thereby improving the use of resources.
\end{abstract}

Keywords: model experimental, experimental precision, Opuntia ficus indica Mill

\section{Introduction}

Although 'Gigante' cactus pear (Opuntia ficus indica Mill) is considered the forage crop with the highest productivity, yields recorded in Brazil do not reach satisfactory levels (Marques et al., 2017). Thus, due to factors limiting the cultivation of this crop, several studies have been carried out aimed at providing alternatives that favor its sustainable development, associating highest performance with food security (Lima et al., 2016; Donato et al., 2017; Dantas et al., 2017).

Field trials with 'Gigante' cactus pear are conducted in several Brazilian regions with the objective of improving production, decreasing costs and increasing efficiency of agricultural inputs, thereby providing minimum conditions for feasible farming (Dantas et al., 2017). Successful investigations consist of observing statistical differences between treatments. Accordingly, finding out the suitable size and shape of the experimental plot is necessary so as to lessen the experimental error (Cargnelutti Filho et al., 2018).

The plot size of the experimental plot should not be determined indiscriminately. The estimation of the plot size must take into account site-specific soil and climate conditions under which the crop is grown since the optimum plot size varies with the heterogeneity of the experimental area (Donato et al., 2018). Therefore, adopting a suitable plot size has a direct impact on the precision and quality of the experimental data (Cargnelutti Filho et al., 2014; Schmildt et al., 2016; Lavezo et al., 2017). 
The optimum plot size for 'Gigante' cactus pear can be estimated by several procedures; however, a few methods stand out owing to their efficiency, simplicity and high accuracy: modified maximum curvature method (Lessman \& Atkins, 1963), Hatheway's convenient plot size method (Hatheway, 1961), linear and quadratic response plateau models (Paranaíba et al., 2009), and comparison of variances method (Vallejo \& Mendonza, 1992).

Therefore, the objective of this study was to compare the methods for estimating plot sizes for evaluation of phenotypic characteristics of 'Gigante' forage cactus pear. The methods are: modified maximum curvature, Hatheway's method, linear response plateau, quadratic response plateau, and comparison of variances method.

\section{Material and Methods}

\subsection{Experimental Characterization: Soil, Climate and Experimental Delimitation}

The experiment was carried out at Federal Institute Baiano, campus Guanambi, state of Bahia, Brazil, located at $14^{\circ} 13^{\prime} 30^{\prime \prime} \mathrm{S}, 42^{\circ} 46^{\prime} 53^{\prime \prime} \mathrm{W}$ and altitude of $525 \mathrm{~m}$. The soil on the experimental area is a Litolic Neosol, with flat to undulating relief (EMBRAPA, 2013). Evaluations began on the 930 days after planting, during which annual mean rainfall and temperature were $670.2 \mathrm{~mm}$ and $25.9^{\circ} \mathrm{C}$, respectively (CODEVASF, 2018).

Based on the uniformity trial, agronomic practices such as tillage, liming and fertilization, were performed uniformly throughout the experimental area, following the recommendations for the crop (Ramalho et al., 2012). Each plant was considered a basic unit, planted at a spacing of $2.0 \times 0.2 \mathrm{~m}\left(25,000\right.$ plants $\left.^{-1} \mathrm{a}^{-1}\right)$. The whole experimental area consisted of 10 rows with 50 plants on each row. The outer plant rows and the first and last plant of each row were not considered for evaluation (border rows), so that only the eight central rows with 48 plants each were evaluated, that is, 384 basic units.

The cladodes used for establishing the experimental area were collected on the middle third of 600-day-old 'Gigante' cactus pear plants growing on an unharvested field. After selecting the cladodes, they remained in the shade for 15 days to cure. Afterwards, the cladodes were planted facing the east-west direction, with half cladode buried in the soil.

\subsection{Evaluated Agronomic Characteristics}

The vegetative characteristics and how they were measured were: plant height (PH-m), cladode length (CL-cm) and cladode width $(\mathrm{CW}-\mathrm{cm})$, determined with a measuring tape; cladode thickness (CT-mm), determined with a digital caliper rule; number of cladodes (NC-unit), determined by counting; cladode area (CA- $\left.\mathrm{cm}^{2}\right)$, estimated by the equation $\mathrm{CA}=\mathrm{CL} \times \mathrm{CW} \times 0.693$; and total cladode area $\left(\mathrm{TCA}-\mathrm{cm}^{2}\right)$, product of CA and NC. These procedures are commonly used in the literature for cactus pear (Donato et al., 2017). Lastly, fresh weight yield $\left(\mathrm{Mg} \mathrm{ha}^{-1}\right)$ was determined with a weighing scale over the third production cycle.

To size plots, we used combinations between rows and columns that would allow plants to cover the total area within plots on the experimental area. As it indicates the optimum plot size, the coefficient of variation was calculated, by which 15 different plot shapes were used (Table 1). 
Table 1. Arrangement of columns and rows and their respective sizes, corresponding number of plots, basic units composing these plots and area for 'Gigante' cactus pear

\begin{tabular}{|c|c|c|c|c|c|c|}
\hline \multirow{2}{*}{ Columns } & \multirow{2}{*}{ Rows } & \multicolumn{2}{|c|}{ Plot size } & \multirow{2}{*}{ Number of plots } & \multirow{2}{*}{ Basic unit } & \multirow{2}{*}{ Area } \\
\hline & & Width & Length & & & \\
\hline 4 & 48 & 8 & 9.6 & 2 & 192 & 76.80 \\
\hline 8 & 16 & 16 & 3.2 & 3 & 128 & 51.20 \\
\hline 8 & 12 & 16 & 2.4 & 4 & 96 & 38.40 \\
\hline 8 & 8 & 16 & 1.6 & 6 & 64 & 25.60 \\
\hline 4 & 12 & 8 & 2.4 & 8 & 48 & 19.20 \\
\hline 8 & 4 & 16 & 0.8 & 12 & 32 & 12.80 \\
\hline 2 & 12 & 4 & 2.4 & 16 & 24 & 9.60 \\
\hline 4 & 4 & 8 & 0.8 & 24 & 16 & 6.40 \\
\hline 1 & 12 & 2 & 2.4 & 32 & 12 & 4.80 \\
\hline 8 & 1 & 16 & 0.2 & 48 & 8 & 3.20 \\
\hline 1 & 6 & 2 & 1.2 & 64 & 6 & 2.40 \\
\hline 1 & 4 & 2 & 0.8 & 96 & 4 & 1.60 \\
\hline 1 & 3 & 2 & 0.6 & 128 & 3 & 1.20 \\
\hline 1 & 2 & 2 & 0.4 & 192 & 2 & 0.80 \\
\hline 1 & 1 & 2 & 0.2 & 384 & 1 & 0.4 \\
\hline
\end{tabular}

Note. Width (m), Length (m), Area $\left(\mathrm{m}^{2}\right)$.

\subsection{Models for Estimation of Experimental Plot Size}

The modified maximum curvature method associates through a power regression equation the coefficients of variation between plots with their respective sizes (Facco et al., 2018). Using Hatheway's method, convenient plot sizes are estimated through a combination matrix (Sousa et al., 2016). Linear and quadratic response plateau models estimate the optimum plot size by converting a linear or quadratic model, respectively, into a plateau (Guarçoni et al., 2017). Comparison of variances method establishes a hierarchical classification criterion, and after obtaining variances and reduced variances, a homogeneity test is conducted to define the best plot size (Henriques Neto et al., 2009).

The modified maximum curvature method represented by the power function $\mathrm{Y}=\mathrm{a} / \mathrm{x}^{\mathrm{b}}$, determines algebraically the optimum plot size by relating the coefficient of variation (CV) and plot size in basic units (Lessman \& Atkins, 1963).The maximum curvature point is determined by the equation:

$$
\mathrm{X}_{\mathrm{mc}}=\left[\frac{\widehat{\mathrm{A}}^{2} \widehat{\mathrm{B}}^{2}(2 \widehat{\mathrm{B}}+1)}{\widehat{\mathrm{B}}+2}\right]^{\frac{1}{2+2 \mathrm{~B})}}
$$

where, $\mathrm{X}_{\mathrm{mc}}$ is the optimum plot size, $\widehat{\mathrm{A}}$ and $\widehat{\mathrm{B}}$ are the respective estimates of coefficients $\mathrm{A}$ and $\mathrm{B}$ of the power function. This formula was obtained by Meier and Lessman (1971).

To determine the convenient plot size (Hatheway, 1961), the model:

$$
\mathrm{X}^{\mathrm{b}}=\frac{2\left(\mathrm{t}_{1}+\mathrm{t}_{2}\right)^{2} \mathrm{CV}^{2}}{\mathrm{rd}^{2}}
$$

was used, where $\mathrm{X}$ is the plot size in basic units; $\mathrm{CV}$ is the coefficient of variation of plots consisting of one basic unit; $b$ is the index of soil heterogeneity (Smith, 1938), represented by the linear equation: $\log V_{x}=\log V_{1}-$ $b(\log x)$, where $V_{x}$ is the variance between vegetative characteristics for each corresponding plot size, $V_{1}$ is the variance between plots with one basic unit, and $x$ is the plot size in basic units; $t_{1}$ is the critical value of Student's $t$ distribution at the significance level of $\alpha 1 ; t_{2}$ is the critical value of Student's $t$ distribution at significance level $\alpha 2=2(1-\mathrm{P})$ where $\mathrm{P}$ is the probability of obtaining a significant result $(0.80) ; \mathrm{r}$ is the number of replications; and $\mathrm{d}$ is the true difference between two treatments as a percentage of the mean.

Furthermore, concerning Hatheway's method (1961), it is worth considering that $t_{1}$ and $t_{2}$ values fluctuate as to the residual degree of freedom and, consequently, as to the number of treatments and blocks. In this case, we adopted five treatments and four replications to estimate plot sizes. Values for $\mathrm{d}$ were set based on the CV of evaluated characteristics.

The linear response plateau model (Paranaíba et al., 2009) was defined as: 


$$
\mathrm{CV}_{\mathrm{i}}=\left\{\begin{array}{ll}
\beta \mathrm{X}_{0}+\beta_{1} \mathrm{X}_{\mathrm{i}}+\varepsilon i & \text { if, } \mathrm{X}_{\mathrm{i}} \leq \mathrm{X}_{\mathrm{c}} \\
\mathrm{P}+\varepsilon \mathrm{\varepsilon i} & \text { if, } \mathrm{X}_{\mathrm{i}}>\mathrm{X}_{\mathrm{c}}
\end{array}, \mathrm{i}=1, \ldots 15\right.
$$

where, $\mathrm{CV}_{\mathrm{i}}$ is the coefficient of variation between plot sizes $\mathrm{X}_{\mathrm{i}} ; \mathrm{X}_{\mathrm{i}}$ is the plot size in basic units; $\mathrm{X}_{\mathrm{c}}$ is the optimum plot size in basic units; $P$ is the coefficient of variation on the plateau; $\beta_{0}$ is the intercept; $\beta_{1}$ is the angular coefficient; and $\varepsilon \mathrm{i}$ is the random error associated with $\mathrm{CV}_{\mathrm{i}}$ (Castro et al., 2016). The ratio between the optimum plot size and plateau formation was determined. The optimum plot size was calculated by the equation $\mathrm{X}_{\mathrm{c}}=\left(\widehat{\mathrm{P}}-\widehat{\beta}_{0}\right) / \widehat{\beta}_{1}$, where, $\widehat{\beta}_{0}, \widehat{\beta}_{1}$ and $\mathrm{P}$ are parameters of the linear response plateau model.

The quadratic response plateau model estimates the optimum plot size by converting a quadratic function into a plateau, as follows:

$$
\mathrm{CV}_{\mathrm{i}}=\left\{\begin{array}{ll}
\beta_{0}+\beta_{1} \mathrm{X}_{\mathrm{i}}+\beta_{2} \mathrm{X}_{\mathrm{i}}^{2}+\varepsilon \mathrm{if}, \mathrm{X}_{\mathrm{i}} \leq \mathrm{X}_{\mathrm{c}} \\
\mathrm{P}+\varepsilon \mathrm{i} & \text { if, } \mathrm{X}_{\mathrm{i}}>\mathrm{X}_{\mathrm{c}}
\end{array}, i=1, \ldots 15\right.
$$

where, $\beta_{0}, \beta_{1}$ and $\beta_{2}$ are estimated parameters of the quadratic function. If $X_{i} \leq X_{c}$, a quadratic model is produced with the $C V_{i}$ values; If $X_{i}>X_{c}$, the equation establishes a plateau (Rezende et al., 2007). The first derivative of the quadratic equation is the optimum point:

$$
\mathrm{X}_{\mathrm{c}}=-\frac{\beta_{1}}{2 \beta_{2}}
$$

where, $X_{c}$ represents the plateau formation on the quadratic response plateau model:

$$
\mathrm{P}=\beta_{0}-\frac{\beta_{1}^{2}}{4 \beta_{2}}
$$

Through the comparison of variances method, variances are reduced to one basic unit, and then, the variance of each plot is divided by the corresponding number of basic units. Comparisons of consecutive Bartlett's tests are performed for each possible pair of plot size aiming to identify the homogeneity of variance (Steel \& Torrie, 1980). After that, the smallest plot with a statistically different variance was excluded in each test. Finally, based on the homogeneity of variances within a group of plots, the plot composed by the lowest number of basic units was selected.

The original variances $\left(\widehat{\mathrm{V}}_{\mathrm{i}}\right)$ of five plots sized in the field, $96,48,24,12$ and 1, were corrected in relation to the lowest number of basic units (one), as follows:

$$
\begin{aligned}
& \widehat{\mathrm{V}}_{1}^{\prime}=\widehat{\mathrm{V}}_{1} \text {; } \\
& \widehat{\mathrm{V}}_{2}^{\prime}=\frac{\left[\mathrm{e}(\mathrm{d}-1) \widehat{\mathrm{V}}_{2}+(\mathrm{e}-1) \widehat{\mathrm{V}}_{1}\right]}{[\mathrm{e}(\mathrm{d}-1)+(\mathrm{e}-1)]} ; \\
& \widehat{\mathrm{V}}_{3}^{\prime}=\frac{\left[\mathrm{ed}(\mathrm{c}-1) \widehat{\mathrm{V}}_{3}+\mathrm{e}(\mathrm{d}-1) \widehat{\mathrm{V}}_{2}+(\mathrm{e}-1) \widehat{\mathrm{V}}_{1}\right]}{[\mathrm{ed}(\mathrm{c}-1)+\mathrm{e}(\mathrm{d}-1)+(\mathrm{e}-1)]} ; \\
& \widehat{\mathrm{V}}_{4}^{\prime}=\frac{\left[\operatorname{edc}(\mathrm{b}-1) \widehat{\nabla}_{4}+\mathrm{ed}(\mathrm{c}-1) \widehat{\nabla}_{3}+\mathrm{e}(\mathrm{d}-1) \widehat{\nabla}_{2}+(\mathrm{e}-1) \widehat{\nabla}_{1}\right]}{[\operatorname{edc}(\mathrm{b}-1)+\operatorname{ed}(\mathrm{c}-1)+\mathrm{e}(\mathrm{d}-1)+(\mathrm{e}-1)]} ; \\
& \widehat{\mathrm{V}}^{\prime}{ }_{5}=\frac{\left.\operatorname{edcb}(\mathrm{a}-1) \widehat{\mathrm{V}}_{5}+\operatorname{edc}(\mathrm{b}-1) \widehat{\mathrm{V}}_{4}+\mathrm{ed}(\mathrm{c}-1) \widehat{\mathrm{V}}_{3}+\mathrm{e}(\mathrm{d}-1) \widehat{\mathrm{V}}_{2}+(\mathrm{e}-1) \widehat{\mathrm{V}}_{1}\right]}{[\operatorname{edcb}(\mathrm{a}-1)+\operatorname{edc}(\mathrm{b}-1)+\operatorname{ed}(\mathrm{c}-1)+\mathrm{e}(\mathrm{d}-1)+(\mathrm{e}-1)]}
\end{aligned}
$$

where, $\widehat{V}_{i}$ is the original variance; $\widehat{V}_{i}^{\prime}$ is the corrected variance; a is the number of plants on each row; $b$ is the number of rows per split-plot; $\mathrm{c}$ is the number of split-plots per plot; $d$ is the number of plots per block; and $\mathrm{e}$ is the number of blocks.

The reduced variances $\widehat{\mathrm{V}}_{(\mathrm{xi})}$ in relation to one basic unit were estimated by dividing the corrected variances $\left(\widehat{\mathrm{V}}_{\mathrm{i}}^{\prime}\right)$ of several plot sizes by their respective number of basic units, as in the following equations:

$$
\begin{gathered}
\widehat{\mathrm{V}}_{\mathrm{x}=\mathrm{i}}=\frac{\mathrm{S}_{\mathrm{xi}}^{\prime 2}}{\mathrm{x}_{\mathrm{i}}} ; \widehat{\mathrm{V}}_{(\mathrm{x}=180)}=\frac{\widehat{\mathrm{V}}_{1}^{\prime}}{180} ; \widehat{\mathrm{V}}_{(\mathrm{x}=45)}=\frac{\widehat{V}_{2}^{\prime}}{45} ; \\
\widehat{\mathrm{V}}_{\mathrm{x}=15}=\frac{\widehat{\mathrm{V}}_{3}^{\prime}}{15} ; \widehat{\mathrm{V}}_{(\mathrm{x}=5)}=\frac{\widehat{\mathrm{V}}_{4}^{\prime}}{5} ; \widehat{\mathrm{V}}_{(\mathrm{x}=1)}=\widehat{\mathrm{V}}_{5}^{\prime}
\end{gathered}
$$

\subsection{Statistical Analysis}

Statistical procedures were carried out on Excel $^{\circledR}$ spreadsheets (Donato et al., 2008, 2018) and using the software R (R Development Core Team, 2012). 


\section{Results and Discussion}

Based on the soil heterogeneity coefficient (b), the experimental area was classified as heterogeneous, with regression coefficients higher than 0.7 for all evaluated traits. These experimental conditions indicate that increasing plot size is more effective than increasing the number of replicates when aiming at higher experimental precision (Hou et al., 2015). However, once the optimum plot size is determined, further increases in precision may be obtained by using more replicates (Souza et al., 2018).

Optimum plot sizes for 'Gigante' cactus pear were determined using the methods modified maximum curvature, Hatheway's convenient plot size, linear response plateau, quadratic response plateau and comparison of variances method. With the modified maximum curvature method, the optimum plot size for yield contained eight basic units or $3.2 \mathrm{~m}^{2}$. As for the following vegetative characteristics: plant height, cladode area, total cladode area, cladode length, cladode width, cladode thickness, and number of cladodes, the optimum plot sizes were four $\left(1.6 \mathrm{~m}^{2}\right)$, four $\left(1.6 \mathrm{~m}^{2}\right)$, seven $\left(2.8 \mathrm{~m}^{2}\right)$, three $\left(1.2 \mathrm{~m}^{2}\right)$, three $\left(1.2 \mathrm{~m}^{2}\right)$, four $\left(1.6 \mathrm{~m}^{2}\right)$ and six $\left(2.4 \mathrm{~m}^{2}\right)$ basic units (plants) per plot, respectively (Table 2 ).

Table 2. Number of basic units composing the optimum plot sizes for 'Gigante' forage cactus pear estimated by the modified maximum curvature method (MMC), convenient plot size (CPS), linear response plateau model (LRP), quadratic response plateau model (QRP) and comparison of variances method (CVM). Coefficient of variation associated to plot sizes (CV), Optimum plot size (OPS)

\begin{tabular}{|c|c|c|c|c|c|c|c|c|c|c|}
\hline \multirow{2}{*}{ Trait } & \multicolumn{2}{|c|}{ MMC } & \multicolumn{2}{|c|}{ CPS } & \multicolumn{2}{|c|}{ LRP } & \multicolumn{2}{|c|}{ QRP } & \multicolumn{2}{|c|}{ CVM } \\
\hline & OPS & $\mathrm{CV}$ & OPS & $\mathrm{CV}$ & OPS & $\mathrm{CV}$ & OPS & $\mathrm{CV}$ & OPS & $\mathrm{CV}$ \\
\hline Yield (Y) & 7.72 & 18.33 & 2.25 & 50.13 & 7.58 & 9.11 & 11.31 & 9.11 & 12.00 & 48.67 \\
\hline Plant height (PH) & 3.42 & 10.94 & 2.75 & 18.69 & 7.96 & 4.68 & 11.24 & 4.68 & 12.00 & 17.75 \\
\hline Total cladode area (TCA) & 6.19 & 16.17 & 2.25 & 39.96 & 7.30 & 7.91 & 11.04 & 7.91 & 12.00 & 39.11 \\
\hline Number of cladodes (NC) & 5.97 & 16.66 & 2.75 & 36.50 & 8.81 & 8.05 & 15.42 & 7.49 & 12.00 & 34.47 \\
\hline Cladode thickness (CT) & 3.49 & 21.20 & 3.00 & 28.96 & 8.50 & 13.88 & 15.37 & 13.53 & 12.00 & 22.45 \\
\hline Cladode area (CA) & 3.72 & 7.26 & 2.45 & 13.58 & 9.25 & 2.24 & 19.58 & 1.81 & 96.00 & 13.05 \\
\hline Cladode length (CL) & 2.14 & 4.96 & 2.50 & 6.89 & 9.46 & 1.30 & 19.48 & 1.10 & 12.00 & 6.63 \\
\hline Cladode width (CW) & 2.77 & 5.22 & 2.10 & 8.03 & 9.07 & 1.67 & 20.24 & 1.07 & 12.00 & 7.64 \\
\hline
\end{tabular}

The range of plot sizes estimated by modified maximum curvature method was five basic units, ranging from three to eight basic units (Table 2). Hence, experimenters may benefit from a more detailed recommendation for each phenotypic characteristic when aiming to carry out a specific or individual evaluation of one or more traits (Donato et al, 2018), thereby improving factors concerning the study, such as experimental area, time, financial resources, and labor (Cargnelutti Filho et al., 2018).

However, since studies on forage cactus generally investigate all aforementioned vegetative traits, the largest plot size must be used to allow measuring every characteristic, as reported by Donato et al (2008). For this reason, eight basic unit plot sizes estimated by the modified maximum curvature is the one to be used for experiments on forage cactus pear (Guimarães et al., 2019).

Paludo et al. (2015) further explained that the modified maximum curvature method, despite its algebraic precision at determining the optimum plot size, estimates smaller plot sizes than other estimating methods, but with a better $\mathrm{R}^{2}$. Additionally, this method allows estimating intermediate plot sizes in comparison with pre-established basic unit plot sizes (Facco et al., 2018).

Using Hatheway's method (Hatheway, 1961), plot sizes were estimated as a function of the true difference between two treatment means (\%). Owing to the specificity of this method, it is only possible to observe differences in response to the treatment effect if the detectable true difference is equal to or greater than the coefficient of variation (CV) of the measured characteristic (Donato et al., 2018).

The optimum plot size was approximately three basic units, regardless of the evaluated vegetative characteristic (Table 2), with four replications and five treatments. The true detectable difference was based on the coefficient of variation of the vegetative characteristic. Sousa et al. (2016) and Donato et al. (2018) reported that Hatheway's method tends to yield too small plot sizes or broad basic unit plot sizes, which makes the practical use of some plot sizes unfeasible. 
Hatheway's methodology allows the experimenter to select the suitable plot size in line with the objective of the study by using a statistical matrix combining factors such as coefficient of variation, true difference (\%) between treatment means, number of treatments and number of replications; nonetheless, researchers should be cautious with plot sizes estimated from combinations of these factors, as some estimates are of low practical use (Sousa et al., 2016).

Furthermore, it is possible with Hatheway's method to select the experimental plot based on the experimental area efficiency use. The experimenter can either use larger plots (three basic units) with fewer replications (four) or smaller plots (two basic units) with more replications (ten), with no change in precision when evaluating the yield of 'Gigante' forage cactus pear. This selection criterion defines the smallest experimental area associated with the highest precision by choosing the lowest area efficiency use (Donato et al., 2018).

The linear response plateau model estimated plots with similar sizes across phenotypic characteristics, with a range of two basic units among plot sizes. Eight basic unit plots $\left(3.2 \mathrm{~m}^{2}\right)$ are recommended for evaluating plant height, total cladode area and yield; for the number of cladodes and cladode thickness, the optimum plot size consisted of nine basic units $\left(3.6 \mathrm{~m}^{2}\right)$; and for cladode area, length and width, a plot size of 10 basic units is recommended $\left(4 \mathrm{~m}^{2}\right)$ (Table 2$)$.

Both the linear response plateau and Hatheway's methods estimated plots with similar sizes regardless of the vegetative characteristic. However, plot sizes estimated by the modified maximum curvature method were the most uneven across characteristics. This discrepancy between plot sizes might be linked to either the natural variability of the evaluated trait (Cargnelutti Filhoet al., 2018) or specificity of the method (Donato et al., 2008). The latter is the case of this study.

Several studies have been carried out on the use of the aforementioned methods for estimating the optimum plot size: modified maximum curvature method (Sousa et al., 2016; Cargnelutti Filhoet al., 2018; Guimarães et al., 2019), Hatheway's method (Sousa et al., 2016; Cargnelutti Filhoet al., 2016; Donato et al., 2018) andlinear response plateau regression (Sousa et al., 2015; Leonardo et al., 2014; Sampaio Filhoet al., 2019). These studies agree on the dependent relationship between plot size and CV of the characteristic; thus, characteristics with higher variability need larger unit areas to show significant differences between treatments (Donato et al., 2018).

The results presented by these methods were not similar. With the only exception of yield, the LRP had a larger plot size than the MMC. The literature has shown LRP more frequently than MMC (Paranaíba et al., 2009; Oliveira et al., 2011; Brito et al., 2012). Concerning the significance of the models, the coefficients were significant at probability levels between 0 '***' and ' '1 (Figure 1). 

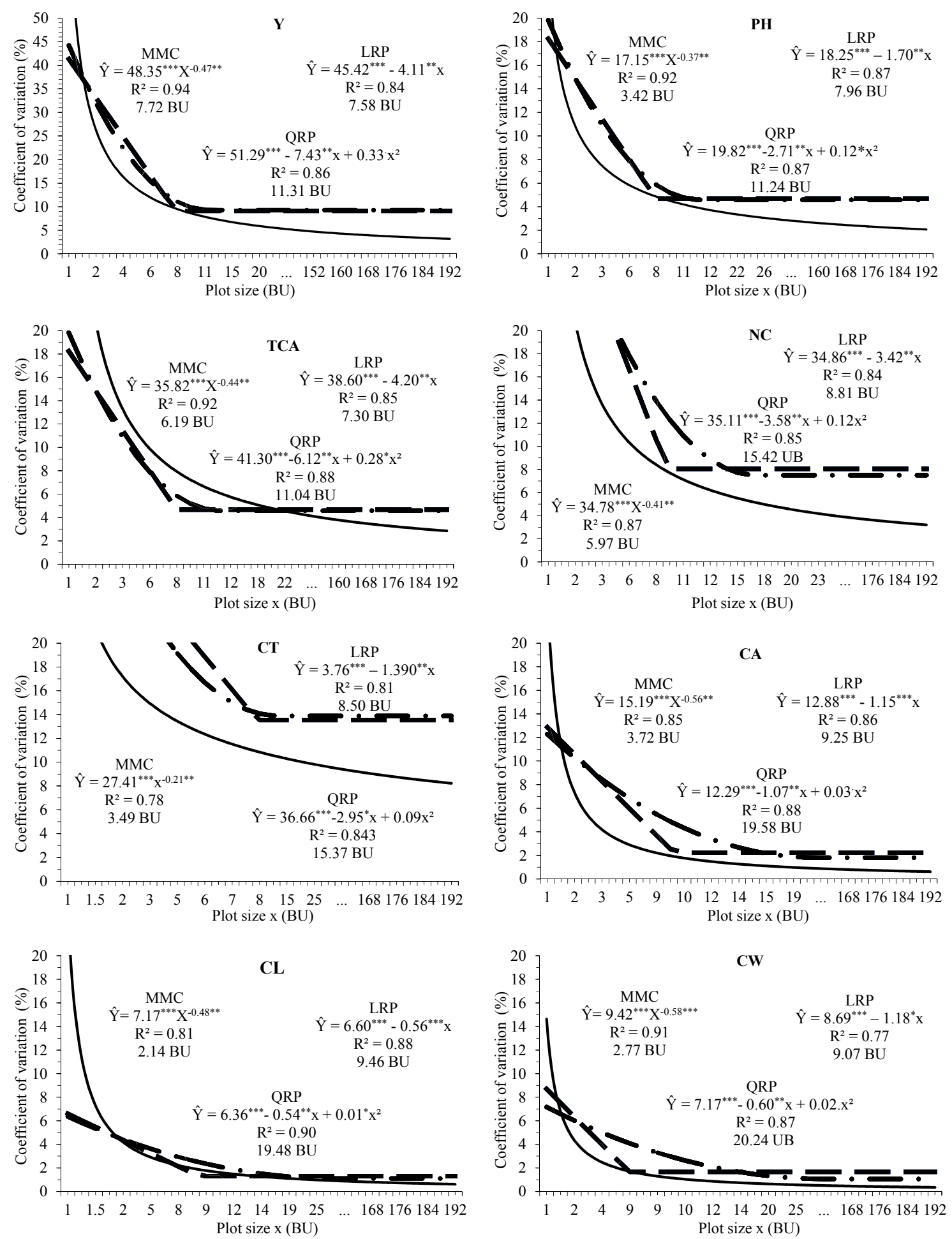

Figure 1. Plot sizes estimated by the regression models: modified maximum curvature-MMC ( - ), linear response plateau-LRP (---) and quadratic response plateau-QRP (----), with their respective equations, plot sizes

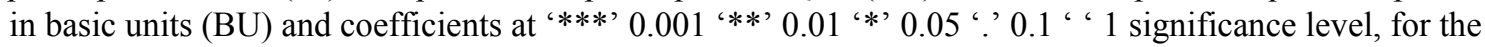
characteristics: $\mathrm{Y}=$ yield, $\mathrm{PH}=$ plant height, $\mathrm{TCA}=$ total cladode area, $\mathrm{NC}=$ number of cladodes, $\mathrm{CT}=$ cladode thickness, $\mathrm{CA}=$ cladode area, $\mathrm{CL}=$ cladode length and $\mathrm{CW}=$ cladode width

Modified maximum curvature method had the best-fitting regression models, with coefficient of determination $\left(\mathrm{R}^{2}\right)$ ranging from 0.81 to 0.94 ; whereas the linear response plateau method had $\mathrm{R}^{2}$ ranging from 0.77 to 0.88 (Figure 1). Higher values of $\mathrm{R}^{2}$ coupled with the significance of coefficients composing the model ensure higher 
reliability when determining the optimum plot size by the modified maximum curvature method (Figure 1). The best model fitting for this method was also reported by Sousa et al. (2015), Donato et al. (2008) and Viana et al. (2002) for sunflower, banana and cassava, respectively.

The quadratic response plateau regressions estimated larger plot sizes than linear response plateau, modified maximum curvature and Hatheway's methods for 'Gigante' forage cactus pear. Likewise, Oliveira et al. (2014) found larger plots when using quadratic response plateau in comparison with the linear response plateau models for studies on genotypes of banana. According to these authors, the relationship between the increase in plot size and reduction in CV may assume a quadratic behavior. Nonetheless, linear response plateau regression models were better for estimating the optimum plot size.

Complementary results were reported by Peixoto et al. (2011) by comparing the response plateau regression models for estimating plot sizes for experiments with passion fruit. Therefore, based on the parameters that define the quality of the model, coefficient of determination, significance of coefficients and plot size, the authors pointed out the superiority of the linear response plateau model, as similarly observed herein (Figure 1).

The relationship between the experimental precision (CV) and plot size directly varies with the crop and measured characteristic; thus, linear response plateau and modified maximum curvature had the best-fitting models when defining the optimum plot size. Guarçoni et al. (2017) and Donato et al. (2008) reported the best plot size estimated using linear response plateau and modified maximum curvature, respectively.

Silva et al. (2012), using modified maximum curvature, linear response plateau and quadratic response plateau, found different plot sizes for radish. They concluded that plot sizes with 21 to 63 basic units are suitable for an adequate experimental design. Within this range, segmented quadratic response plateau regression models estimated the largest plots, followed by the linear response plateau and modified maximum curvature methods.

With comparison of variances method, an inversely proportional ratio between reduced variances and plot size in basic units is observed. The effect of decreasing variance with increasing plot size has been already reported by several authors (Henriques Netoet al., 2009; Donato et al., 2008; Viana et al., 2002; Vallejo \& Mendoza, 1992; Ortiz, 1995). This analysis is the defining point for estimating the optimum experimental plot size.

Through the comparison of variances method, a 96 basic unit plot size was ideal for measuring cladode area since it had lower variance than plots consisting of one, 12, 24 and 48 basic units. As for the remaining characteristics, plot sizes with one, 12, 24, 48 and 96 basic units did not differ from one another with respect to variance; therefore, 12 basic unit plot sizes are recommended as this size has the lowest number of basic units among sizes of equal variances (Table 2).

In studying methods for estimating optimum size of plots, Henriques Neto et al. (2009), Donato et al. (2008), Viana et al. (2002), Vallejo and Mendoza (1992), and Ortiz (1995) found the largest plots by using comparison of variances method for wheat, banana, cassava, potato and banana, respectively. Notwithstanding, studies diverged as to the definition of the most suitable method. Henriques Neto et al. (2009), Vallejo and Mendoza (1992) and Ortiz (1995) considered comparison of variances method as the most reliable method for estimating the optimum plot size, whereas Donato et al. (2008) and Viana et al. (2002) reported the best results with the modified maximum curvature method.

As shown in Table 2, plot size estimates varied with both methods and characteristics. Hatheway's method estimated the lowest number of basic units, with a single plot size for all characteristics, with four replicates and five treatments. The largest plot sizes were estimated with comparison of variances method, with 12 basic unit plots being suitable for most measured characteristics.

Every model evaluated in this study estimated intermediate sizes in relation to predetermined basic units, except for comparison of variances method, which establishes a value of optimum plot size that coincides with what was previously determined.

In trials with 'Gigante' cactus pear, characteristics studied herein are normally evaluated, so it is necessary to select optimum plot sizes that meet the minimum requirement for all characteristics. Furthermore, when sizing plots, one must consider the specific nature of the crop regarding morphology, presence of spines and shoot architecture as these are characteristics that hinder data collection in the field.

\section{Conclusions}

Optimum plot size estimates varied with both methods and measured characteristics.

Quadratic response plateau model estimated the largest plot sizes, whereas the smallest estimates were determined by Hatheway's method. 
Comparison of variances method estimated intermediate plot sizes in comparison with the other method for most measured characteristics.

The modified maximum curvature determined plot sizes that are more consistent with studies with 'Gigante' forage cactus.

Ten basic unit plot sizes estimated by linear response plateau model can be used with high precision, practical feasibility for carrying out experiments, and significant optimization of resources.

\section{Acknowledgements}

To the Federal Institutes: Instituto Federal do Amazonas (IFAM) and Instituto Federal Baiano (IF-Baiano) and to the Universidade Estadual de Montes Claros (UNIMONTES). This study was conducted with support from the Coordenação de Aperfeiçoamento de Pessoal de Nível Superior (CAPES, Brazil)-Finance Code 001.

\section{References}

Cargnelutti Filho, A., Toebe, M., Burin, C., Casarotto, G., \& Alves, B. M. (2014). Planejamentos experimentais em nabo forrageiro semeado a lanço e em linha. Bioscience Journal, 30(3), 677-686.

Cargnelutti Filho, A., Storck, L., Lúcio, A. D., Toebe, M., \& Alves, B. M. (2016). Tamanho de unidades experimentais básicas e tamanho ótimo de parcelas para nabo-forrageiro. Pesquisa Agropecuária Brasileira, 51(4), 309-319. https://doi.org/10.1590/S0100-204X2016000400003

Cargnelutti Filho, A., Araújo, M. M., Gasparin, E., \& Foltz, D. R. B. (2018). Dimensionamento amostral para avaliação de altura e diâmetro de plantas de timbaúva. Floresta e Ambiente, 25(1), 1-9. https://doi.org/ 10.1590/2179-8087.121314

Castro, M. R., Pinheiro, S. R. F., Lima, H. J. D., Pires, A. V., Vieira, D. J., Abreu, L. R. A., ... Oliveira, R. G. (2016). Relações metionina + cistina: lisina digestíveis para codornas de corte machos em fase de terminação. Revista Brasileira de Saúde e Produção Animal, 17(2), 162-173. https://doi.org/10.1590/ S1519-99402016000200004

CODEVASF. (2018). Dados meteorológicos. 2a Superintendência Regional, Núcleo Avançado de Guanambi, Estação Agrometeorológicos de Ceraíma. Núcleo Avançado de Guanambi ( $\left.2^{\mathrm{a}} \mathrm{NGU}\right)$.

Brito, M. C. M., Faria, G. A., Morais, A. R., Souza, E. M., \& Dantas, J. L. L. (2012). Estimação do tamanho ótimo de parcela via regressão antitônica. Revista Brasileira de Biometria, 30(3), 353-366.

Dantas, S. F. A., Lima, G. F. C., \& Mota, E. P. (2017). Viabilidade econômica da produção de palma forrageira irrigada e adensada no semiárido Potiguar. Revista iPecege, 3(1), 59-74. https://doi.org/10.22167/r.ipecege. 2017.1.59

Donato, P. E. R., Donato, S. L. R., Silva, J. A., Pires, A. J. V., \& Silva Junior, A. A. (2017). Extraction/exportation of macronutrients by cladodes of 'Gigante' cactus pear under different spacing and organic fertilizer. Revista Brasileira de Engenharia Agrícola e Ambiental, 21(4), 238-243. https://doi.org/ 10.1590/1807-1929/agriambi.v21n4p238-243

Donato, S. L. R., Silva, J. A. da, Guimarães, B. V. C., \& Silva, S. de O. (2018a). Experimental planning for the evaluation of phenotipic descriptors in banana. Revista Brasileira Fruticultura, 40(5), 1-13. https://doi.org/ 10.1590/0100-29452018962

Donato, S. L. R., Siqueira, D. L. de, Silva, S. O., Cecon, P. R., Silva, J. A. da, \& Salomão, L. C. C. (2008b). Estimativas de tamanho de parcelas para avaliação de descritores fenotípicos em bananeira. Pesquisa Agropecuária Brasileira, 43(8), 957-969. https://doi.org/10.1590/S0100-204X2008000800003

EMBRAPA (Empresa Brasileira de Pesquisa Agropecuária). (2013). Sistema brasileiro de classificação de solos (3rd ed., p. 353). Brasília: Embrapa Informação Tecnológica.

Facco, G., Cargnelutti Filho, A., Lavezo, A., Schabarum, D. E., Chaves, G. G., \& Silveira, D. L. (2018). Basic experimental unit and plot sizes for fresh matter of sunn hemp. Ciência Rural, 48(1), e20170660. https://doi.org/10.1590/0103-8478cr20170660

Guarçoni, R. C., Souza, J. L. de, Favarato, L. F., Angeletti, M. da P., \& Bahiense, D. V. (2017). Determinação do tamanho ótimo de parcela experimental para experimentos com repolho utilizando simulação e métodos de estimação. Revista Cientifica Intelletto, 2(2), 79-87. https://doi.org/10.17648/intelletto-2525-9075-v2-n2-09 
Guimarães, B. V. C., Donato, S. L. R., Aspiazú, I., Azevedo, A. M., \& Carvalho, A. J. de (2019). Size of plots for experiments with cactus pear cv. Gigante. Revista Brasileira de Engenharia Agrícola e Ambiental, 23(5), 347-351. https://doi.org/10.1590/1807-1929/agriambi.v23n5p347-351

Hatheway, W. H. (1961). Convenient plot size. Agronomy Journal, 53(4), 279-280. https://doi.org/10.2134/ agronj1961.00021962005300040025x

Henriques Neto, D., Sediyama, T., Souza, M. A., Leite, L. F. C., \& Blanco, F. F. (2009). Tamanho de parcela para avaliação da produção em trigo irrigado, sob dois sistemas de plantio. Revista Ciência Agronômica, 40(1), 86-93.

Hou, Z., Xu, Q., Hartikainen, S., Antilla, P., Packalen, T., Matti Maltamo, M., \& Tokola, T. (2015). Impact of Plot Size and Spatial Pattern of Forest Attributes on Sampling Efficacy. Fundamental Research, 61(5), 847-860. https://doi.org/10.5849/forsci.14-197

Lavezo, A., Cargnelutti Filho, A., Bem, C. M. D., Burin, C., Kleinpaul, J. A., \& Pezzini, R. V. (2017). Plot size and number of replications to evaluate the grain yield in oat cultivars. Bragantia, 76(4), 512-520. https://doi.org/ $10.1590 / 1678-4499.2016 .410$

Leonardo, F. A. P., Pereira, W. E., Silva, S. de M., Araújo, R. da C., \& Mendonça, R. M. N. (2014). Tamanho ótimo da parcela experimental de abacaxizeiro 'Vitória'. Revista Brasileira de Fruticultura, 36(4), 909-916. https://doi.org/10.1590/0100-2945-396/13

Lessman, K. J., \& Atkins, R. E. (1963). Optimum plot size and relative efficiency of lattice designs for grain sorghum yield test. Crop Science, 3(1), 477-481. https://doi.org/10.2135/cropsci1963.0011183X0003000 $60006 x$

Lima, G. F. C., Rego, M. M. T., Dantas, F. D. G., Lôbo, R. N. B., Silva, da J. G. M., \& Aguiar, E. M. de (2016). Morphological characteristics and forage productivity of irrigated cactus pear under different cutting intensities. Revista Caatinga, 29(2), 481-488. https://doi.org/10.1590/1983-21252016v29n226rc

Marques, O. F. C., Gomes, L. S. P., Mourthé, M. H. F., Braz, T. G. dos S., \& Pires Neto, O. de S. (2017). Palma forrageira: Cultivo e utilização na alimentação de bovinos. Caderno de Ciências Agrárias, 9(1), 75-93.

Meier, V. D., \& Lessman, K. J. (1971). Estimation of optimum field plot shape and size for testing yield in Crambe abyssinica Hochst. Crop Science, 11(3), 648-650. https://doi.org/10.2135/cropsci1971.0011183X $001100050013 \mathrm{x}$

Oliveira, G. M. V., Mello, J. M., Lima, R. R., Scolforo, J. R. S., \& Oliveira, A. D. (2011). Tamanho e forma de parcelas experimentais para Eremanthus erythropappus. CERNE, 17(3), 327-338. https://doi.org/10.1590/ S0104-77602011000300006

Oliveira, E. A., Cecon, P. R., Silva, F. F., Lima, C. G. de, Donato, S. L. R., \& Dias, C. T. dos S. (2014). Componentes principais na estimação do tamanho ótimo de parcelas em experimentos envolvendo genótipos de bananeira. Revista Brasileira de Biometria, 32(2), 190-200.

Ortiz, R. (1995). Plot techniques for assessment of bunch weight in banana trials under two systems of crop management. Agronomy Journal, 87(1), 63-69. https://doi.org/10.2134/agronj1995.0002196200870001 $0011 x$

Paludo, A. L., Lopes, S. J., Brum, B., Storck, L., Santos, D. dos, \& Haesbaert, F. (2015). Tamanho de parcela e número de repetições para mamoneira em diferentes espaçamentos entre plantas. Revista Caatinga, 28(4), 253-258. https://doi.org/10.1590/1983-21252015v28n428rc

Paranaíba, P. F., Ferreira, D. F., \& Morais, A. R. (2009). Tamanho ótimo de parcelas experimentais: Proposição de métodos de estimação. Revista Brasileira de Biometria, 27(1), 255-268.

Peixoto, A. P. B., Faria, G. A., \& Morais, A. R. (2011). Modelos de regressão com platô na estimativa do tamanho de parcelas em experimento de conservação in vitro de maracujazeiro. Ciência Rural, 41(11), 1907-1913. https://doi.org/10.1590/S0103-84782011001100010

Ramalho, M. A. P., Ferreira, D. F., \& Oliveira, A. C. de (2012). Experimentação em genética e melhoramento de plantas (p. 305). Lavras: Editora da UFLA.

Rezende, D. M. L. C., Muniz, J. A., Ferreira, D. F., Silva, F. F., \& Aquino, L. H. (2007). Ajuste de modelos de platô de resposta para a exigência de zinco em frangos de corte. Ciência e Agrotecnologia, 31(2), 468-478. https://doi.org/10.1590/S1413-70542007000200030 
R Development Core Team. (2012). The R Project for Statistical Computing. Retrieved January 17, 2019, from http://www.R-project.org

Sampaio Filho, O. M., Silva, S. de O., Donato, S. L. R., Silva, S. A., \& Silva, M dos S. da. (2019). Optimum experimental plot size in the castor bean. Revista Ciência Agronômica, 50(2), 276-281. https://doi.org/ $10.5935 / 1806-6690.20190032$

Schmildt, E. R., Schmildt, O., Cruz, C. D., Cattaneo, L. F., \& Ferreguetti, G. A. (2016). Optimum plot size and number of replications in papaya field experiment. Revista Brasileira de Fruticultura, 38(2), 1-9. https://doi.org/10.1590/0100-29452016373

Silva, L. F. de O., Campos, K. A., Morais, A. R. de, Cogo, F. D., \& Zambon, C. R. (2012). Tamanho ótimo de parcela para experimentos com rabanetes. Revista Ceres, 59(5), 624-629. https://doi.org/10.1590/ S0034-737X2012000500007

Sousa, R. P. de, Silva, P. S. L., Assis, J. P. de, Silva, J. da, Oliveira, V. R. de, \& Oliveira, A. M. de P. (2015). Tamanho ótimo de parcela para avaliação do rendimento de grãos do girassol. Revista Brasileira de Engenharia Agricola e Ambiental, 19(1), 21-26. https://doi.org/10.1590/1807-1929/agriambi.v19n1p21-26

Sousa, R. P., Silva, P. S. L., \& Assis, J. P. (2016). Tamanho e forma de parcelas para experimentos com girassol. Revista Ciência Agronômica, 47(4), 683-690.

Smith, H. F. (1938). An empirical law describing heterogeneity in the yields of agricultural crops. Journal of Agricultural Science, 28(1), 1-23. https://doi.org/10.1017/S0021859600050516

Steel, R. G. D., \& Torrie, J. H. (1980). Principles and procedures of statistics (2nd ed., p. 633). New York: McGraw-Hill Book.

Vallejo, R. L., \& Mendoza, H. A. (1992). Plot technique studies on sweet potato yield trials. Journal of the American Society for Horticultural Science, 117(3), 508-511. https://doi.org/10.21273/JASHS.117.3.508

Viana, A. E. S., Sediyama, T., Cecon, P. R., Lopes, S. C., \& Sediyama, M. A. N. (2002). Estimativas de tamanho de parcela em experimentos com mandioca. Horticultura Brasileira, 20(1), 58-63. https://doi.org/10.1590/ S0102-05362002000100011

\section{Copyrights}

Copyright for this article is retained by the author(s), with first publication rights granted to the journal.

This is an open-access article distributed under the terms and conditions of the Creative Commons Attribution license (http://creativecommons.org/licenses/by/4.0/). 